Агросистемы будущего

Симбиотические взаимодействия

\title{
ВЛИЯНИЕ МУТАЦИИ В ГЕНЕ Sym26 НА ОРГАНИЗАЦИЮ ТУБУЛИНОВОГО ЦИТОСКЕЛЕТА В КЛУБЕНЬКАХ ГОРОХА ПОСЕВНОГО (Pisum sativum L.)*
}

\author{
А.Б. КИТАЕВА, В.Е. ЦЫГАНОВ
}

Симбиотический клубенек - уникальный орган, который формируется на корнях бобовых растений. Для клубеньков недетерминированного типа (с продолжительной активностью меристемы) (F. Guinel, 2009) характерна дифференцировка как клеток клубенька, так и инфицировавших его бактерий, которые преобразуются в специализированную для азотфиксации форму бактероиды. Бактероиды, окруженные мембраной растительного происхождения, формируют органеллоподобные симбиосомы (А. Tsyganova с соавт., 2018; T. Coba de la Peca c coaвт., 2018). Дифференцировка клеток в центральной части клубенька приводит к формированию неинфицированных (свободных от бактерий) и инфицированных клеток, заполненных многими тысячами симбиосом (А. Tsyganova с соавт., 2018). В результате продолжительной активности меристемы в недетерминированном клубеньке формируется гистологическая зональность. Различают меристему, зону инфекции, зону азотфиксации, а в основании зрелого клубенька формируется зона старения (F. Guinel, 2009). Очевидно, что тубулиновый цитоскелет играет важную роль в развитии клубенька, но до недавнего времени основное внимание уделялось ранним стадиям развития клубенька (A. Timmers, 2008), и лишь недавно было выявлено, что тубулиновый цитоскелет играет ключевую роль в дифференцировке клеток клубенька (А. Kitaeva с соавт., 2016). Так, было показано, что в клубеньках гороха посевного (Pisum sativum L.) и люцерны слабоусеченной (Medicago truncatula Gaertn.) выход бактерий в цитоплазму растительной клетки препятствует формированию свойственного неинфицированным клеткам упорядоченного паттерна кортикальных микротрубочек, ориентированных параллельно друг другу и перпендикулярно продольной оси клетки; это ведет к появлению неупорядоченного паттерна, способствующего переходу инфицированных клеток к изодиаметрическому росту (А. Kitaeva с соавт., 2016). Эндоплазматические микротрубочки создают матрицу для роста инфекционных нитей, поддерживают расположение инфекционных капель и симбиосом в инфицированных клетках (A. Kitaeva с соавт., 2016). Тем не менее не были изучены изменения в организации тубулинового цитоскелета при старении клеток клубенька. В настоящем исследовании с использованием иммуноцитохимического анализа и конфокальной лазерной сканирующей микроскопии мы изучили организацию тубулинового цитоскелета в клубеньках мутантной линии гороха SGEFix-3 (sym26). Для этого мутанта характерно формирование неэффективных клубеньков с преждевременно деградирующими симбиотическими структурами (Т. Serova с соавт., 2018). Показано, что в 2-недельных клубеньках мутантной линии паттерны кортикальных и эндоплазматических микротрубочек не отличались от таковых у исходной линии SGE. Так, кортикальные микротрубочки формировали неупорядоченный паттерн в меристематических и инфицированных клетках и упорядоченный - в неинфицированных и колонизированных клетках. Эндоплазматические микротрубочки окружали ядро в интерфазных клетках, формировали веретена деления и препрофазные пояски при митозе, а также окружали инфекционные нити. В то же время в зоне старения в деградирующих клетках наблюдалась полная деполимеризация тубулинового цитоскелета как в инфицированных, так и в неинфицированных клетках. У исходной линии старение индуцировалось лишь в 4-недельных клубеньках, и в стареющих клетках также наблюдалась деполимеризация микротрубочек. Таким образом, полная деполимеризация микротрубочек в различных типах клеток клубенька может быть цитологическим маркером его старения.

Ключевые слова: бобово-ризобиальный симбиоз, микротрубочки, симбиосома, бактероид, инфекционная нить, старение клубенька, иммунолокализация, Pisum sativum.

Одна из особенностей бобовых растений заключается в их взаимодействии с клубеньковыми бактериями - ризобиями, что приводит к появлению на корнях симбиотических клубеньков. Симбиотический клубенек - уникальный орган, в нем растение создает экологические ниши для ризобий, которые приобретают способность фиксировать атмосферный

\footnotetext{
* Работа выполнена на оборудовании ЦКП «Геномные технологии, протеомика и клеточная биология» ФГБНУ ВНИИСХМ и ЦКП «Клеточные и молекулярные технологии изучения растений и грибов» ФГБУН БИН РАН. Исследования поддержаны РНФ (грант № 16-16-10035).
}

1014 
азот (1). У различных видов Fabaceae симбиотические клубеньки различаются по структуре. Выделяют два основных типа клубеньков - детерминированные и недетерминированные (2). Детерминированные клубеньки характеризуются непродолжительной активностью меристемы, из-за чего принимают шаровидную форму. В недетерминированных клубеньках меристема функционирует длительное время, что приводит к появлению гистологической зональности центральной зоны клубеньков, которые имеют вытянутую форму. В результате выделяются меристема, зона инфекции, в которой ризобии высвобождаются в цитоплазму клеток, зона азотфиксации, в которой они приобретают способность к фиксации азота, дифференцируясь при этом в специализированную форму - бактероиды $(2,3)$. С увеличением возраста клубенька (примерно через 4 нед после инокуляции) в его основании начинает формироваться зона старения (4). Наряду с дифференцировкой бактероидов наблюдается ярко выраженная дифференцировка клеток клубенька (5). При этом часть клеток остается неинфицированными, а инфицированные клетки значительно увеличиваются в объеме, заполняясь при этом многочисленными симбиосомами (бактероидами, отделенными от цитоплазмы растительной клетки мембраной растительного происхождения - симбиосомной мембраной) $(5,6)$. Очевидно, что процесс дифференцировки растительных клеток при развитии симбиотического клубенька сопровождается значительными перестройками цитоскелета (7).

Реорганизация актиновых микрофиламентов была описана как один из ранних ответов на действие Nod факторов (8-10). Актиновые микрофиламенты также необходимы для развития инфекционной нити (813). Недавно было показано участие актиновых микрофиламентов в выходе ризобий в цитоплазму растительных клеток из инфекционных капель и размещении симбиосом (14).

Многочисленные микротрубочки были выявлены в местах инициации инфекции в скрученных корневых волосках еще в середине 1980-х годов $(15,16)$. В дальнейшем было показано участие микротрубочек в скручивании корневых волосков, инициации и росте инфекционной нити (1722). В зрелых клубеньках организация микротрубочек изучалась у люцерны посевной (Medicago sativa L.) (23), сои культурной (Glycine max L.) (24), гороха посевного (Pisum sativum L.) (25) и люпина белого (Lupinus albus L.) (26), но трехмерная организация тубулинового цитоскелета не была описана детально, особенно вокруг инфекционных нитей и инфекционных капель (7). Лишь недавно нами было показано, что в клубеньках гороха и Medicago truncatula (Gaertn.) при дифференцировке клеток наблюдаются изменения в паттерне кортикальных микротрубочек (27). Так, в неинфицированных клетках кортикальные микротрубочки располагаются параллельно друг другу и перпендикулярно продольной оси клетки (27), сходный паттерн характерен для клеток корней гороха в переходной зоне (28, 29). В то же время в инфицированных клетках клубеньков как гороха, так и M. truncatula кортикальные микротрубочки формируют неупорядоченный паттерн, направленный на изодиаметрический рост этих клеток (27). В клубеньках обоих изученных видов эндоплазматические микротрубочки формировали плотную сеть вокруг инфекционных структур - инфекционных нитей и капель, формируя матрицу для их развития (27). Значительные различия наблюдались в паттерне эндоплазматических микротрубочек, формирующих сеть среди симбиосом. Так, у гороха микротрубочки располагались среди симбиосом неупорядоченно, что совпадало с отсутствием упорядоченности в расположении самих симбиосом. В то же время в инфицированных клетках клубеньков $M$. truncatula микротрубочки располага- 
лись параллельно симбиосомам, которые, в свою очередь, занимали положение перпендикулярное клеточной стенке (27).

В настоящем сообщении мы впервые показали, что как естественное, так и индуцированное старение клубеньков сопровождается деполимеризацией микротрубочек.

Цель исследования заключалась в оценке влияния естественного старения и старения, индуцированного мутацией в симбиотическом гене гороха Sym26, приводящей к преждевременной деградации симбиотических структур, на организацию тубулинового цитоскелета в клубеньках.

Методика. В работе использовали исходную линию гороха посевного (Pisum sativum L.) SGE (30) и мутантную линию SGEFix -3 (sym26) (31), образующую неэффективные клубеньки с преждевременной деградацией симбиотических структур (зона старения формируется уже через 2 нед после инокуляции), то есть с фенотипом раннего старения (32). Растения инокулировали штаммом Rhizobium leguminosarum bv. viciae 3841 (33).

Семена стерилизовали концентрированной серной кислотой в течение 15 мин, после чего промывали стерильной водой 10 раз. Растения выращивали в пластиковых сосудах, содержащих 100 г стерильного вермикулита, в климатической камере MLR-352H («Sanyo Electric Co., Ltd», Япония) в режиме день/ночь 16/8 при $21{ }^{\circ} \mathrm{C}$, относительной влажности 75 $\%$ и освещенности 280 мкM фотонов $/\left(\mathrm{M}^{2} \cdot \mathrm{c}\right)$. Для полива использовался безазотный питательный раствор (34). Клубеньки для анализа собирали с 10 растений через 2 нед (в случае исходной линии SGE - через 2 и 4 нед) после инокуляции. Эксперименты проводили в 3-кратной повторности.

Методика фиксации клубеньков и иммунолокализации тубулина описана нами ранее (27). Для визуализации микротрубочек использовали моноклональные мышиные антитела к тубулину (клон DM1A, «Sigma-Aldrich», США) в разведении 1:1000 (инкубация в течение ночи при $4{ }^{\circ} \mathrm{C}$ ). В качестве вторичных антител использовали козьи антитела к мышиному $\gamma$ глобулину, конъюгированные с Alexa Fluor 488 («Life Technologies», США), в разведении 1:500 (инкубация в течение 90 мин при $28^{\circ} \mathrm{C}$ ). Для идентификации ядер и бактерий срезы окрашивали йодидом пропидия $(0,5$ мкг/мл) в течение 7 мин. После промывания срезы помещали под покровные стекла в заключающую среду ProLong Gold® antifade reagent («Thermo Fisher Scientific», США).

Анализ паттерна микротрубочек в клетках клубенька проводили с использованием лазерного сканирующего конфокального микроскопа LSM780 и программного обеспечения ZEN2012 («Carl Zeiss», Германия).

Результаты. Гистологическая организация 2-недельных клубеньков исходной линии SGE не отличалась от описанной ранее (35): выявлялась меристема, зона инфекции и зона азотфиксации (рис. 1, А). У мутантной линии SGEFix-3 (sym26) в 2-недельных неэффективных клубеньках отмечали присутствие меристемы, зоны инфекции, зоны, соответствующей зоне азотфиксации, а также выделялась зона старения (рис. 2, Б), что соответствовало гистологической организации клубеньков этого мутанта, изученной ранее (32).

Организация тубулинового цитоскелета в 2-недельных клубеньках исходной линии SGE была детально описана нами ранее, поэтому в настоящем исследовании ее изучили только у мутантной линии SGEFix ${ }^{-}-3$ (sym26). Для сравнения организации микротрубочек в стареющих клетках дикого типа были также проанализированы 4-недельные клубеньки линии SGE, в которых было возможно выявить такие клетки.

В клубеньках мутантной линии SGEFix--3 (sym26) клетки меристемы характеризовались небольшими размерами, ядро в них занимало цен- 
тральное положение. Кортикальные микротрубочки создавали неупорядоченный паттерн, располагаясь под различными углами друг к другу и часто перекрещивались (см. рис. 2, А, Б). Эндоплазматические микротрубочки в интерфазных клетках опутывали ядро, соединяя его с периферией клетки (см. рис. 2, А, Б). В клетках, претерпевающих митоз, эндоплазматические микротрубочки формировали веретено деления, препрофазный поясок (см. рис. 2, А, Б). Наблюдаемые паттерны кортикальных и эндоплазматических микротрубочек меристематических клеток клубеньков SGEFix-3 (sym26) были сходны с таковыми у исходной линии SGE (27).
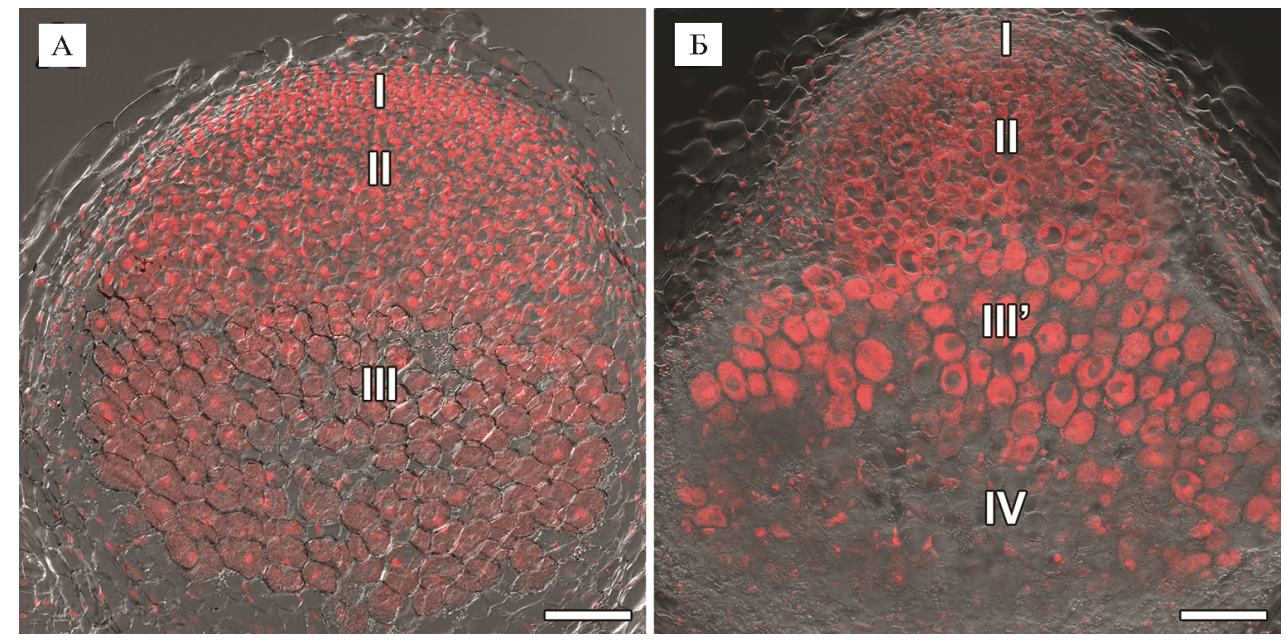

Рис. 1. Гистологическая организация 2-недельных клубеньков у исходной линии SGE (A) и мутантной линии SGEFix-3 (sym26) (Б) гороха посевного (Pisum sativum L.): I - меристема, II зона инфекции, III - зона азотфиксации, III' - зона, соответствующая зоне азотфиксации у исходной линии, IV - зона старения. Конфокальная лазерная сканирующая микроскопия продольных срезов клубеньков (микроскоп LSM780, программное обеспечение ZEN2012, «Carl Zeiss», Германия). Наложение единичных оптических срезов дифференциально-интерференционного контраста и красного каналов. Масштабная линейка - 100 мкм.

В ранней зоне инфекции наблюдали три типа клеток: неинфицированные клетки, колонизированные клетки (то есть клетки, в которых присутствовали инфекционные структуры - инфекционные нити и капли, но из них не происходил выход бактерий в цитоплазму) и инфицированные клетки (см. рис. 2, В, Г). Неинфицированные клетки были лишены эндоплазматических микротрубочек, а кортикальные микротрубочки формировали упорядоченный паттерн - они располагались параллельно друг другу и перпендикулярно продольной оси клетки (см. рис. 2, В, Г). В колонизированных клетках паттерн кортикальных микротрубочек был сходен с таковым в неинфицированных клетках (см. рис. 2, В, Г). При этом наблюдались эндоплазматические микротрубочки, проходящие вдоль инфекционной нити (см. рис. 2, В, Г). В инфицированных клетках кортикальные микротрубочки формировали неупорядоченный паттерн (см. рис. 2, В, Г). Ранее для исходной линии SGE, а также линии дикого типа A17 M. truncatula было показано, что микротрубочки служат матрицей для роста инфекционных нитей и поддерживают инфекционные капли, подготавливая выход ризобий в цитоплазму клеток клубеньков (27).

В поздней зоне инфекции неинфицированные, а особенно инфицированные клетки увеличивались в размерах, при этом в них сохранялись описанные выше паттерны микротрубочек (см. рис. 2, Д, Е). Кроме того, наблюдалась хорошо выраженная сеть эндоплазматических микротрубочек, проходящих между симбиосомами, которые располагались неупорядоченно 
(см. рис. 2, Д, Е).

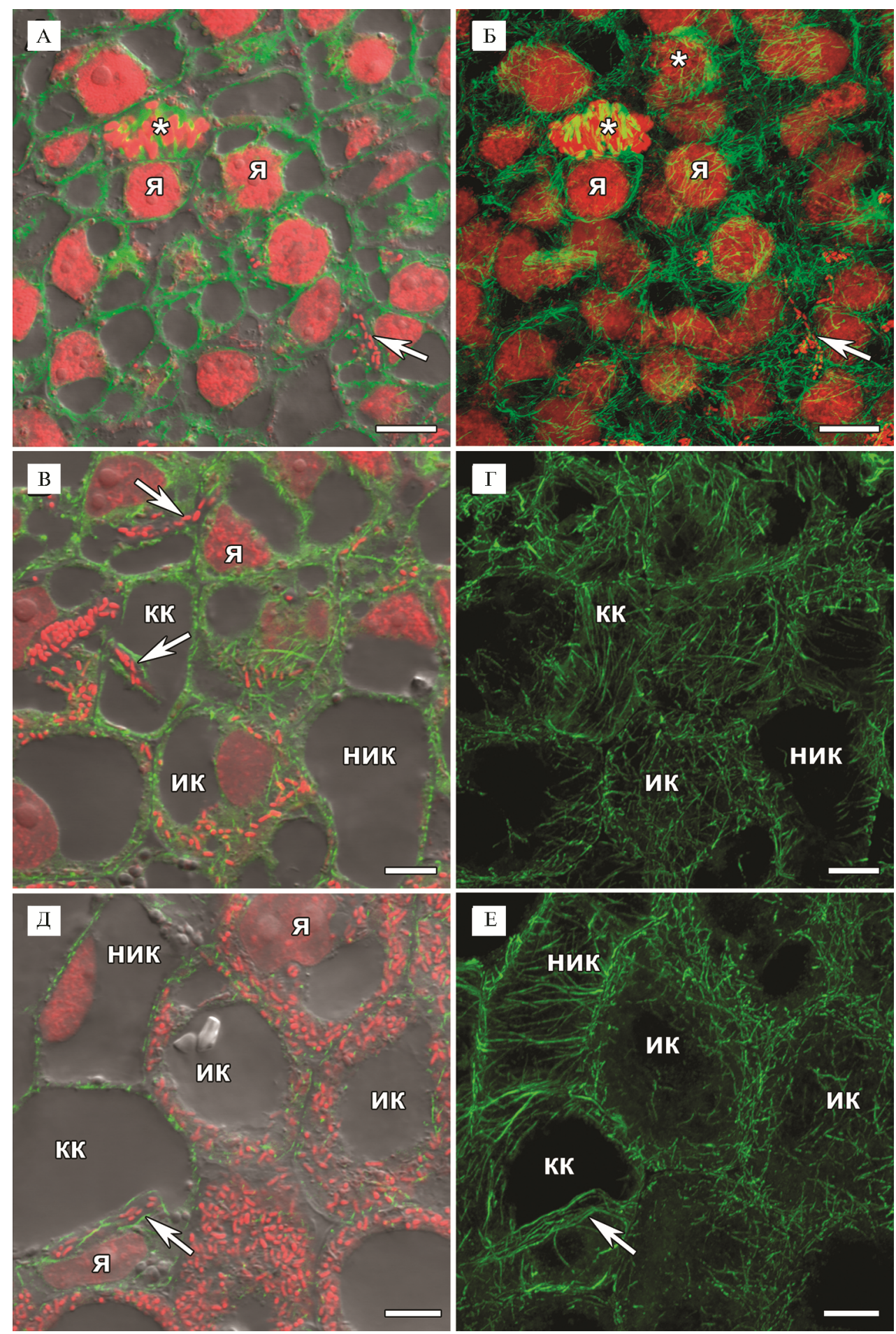

Рис 2. Организация тубулинового цитоскелета в клетках меристемы (А, Б), в клетках ранней $(\mathrm{B}$, Г) и поздней (Д, Е) части зоны инфекции у 2-недельных клубеньков мутантной линии гороха посевного (Pisum sativum L.) SGEFix ${ }^{-}-3$ (sym 26): я - ядро, ик - инфицированная клетка, ник - неинфицированная клетка, кк - колонизированная клетка, стрелки указывают на инфекционные нити, звездочка - фигуры митоза. Конфокальная лазерная сканирующая микроскопия продольных срезов клубеньков (микроскоп LSM780, программное обеспечение ZEN2012, «Carl Zeiss», Германия). Масштабная линейка - 10 мкм.

A-E: иммунолокализация тубулина (микротрубочек) - зеленый канал, окрашива- 
ние ДНК йодидом пропидия (ядра и бактерии) - красный канал.

А, В, Д: наложение единичных оптических срезов дифференциально-интерференционного контраста, зеленого и красного каналов.

Б: проекции максимальной интенсивности зеленого и красного каналов, основанные на z-стеках из 50 оптических срезов.

Г, E: проекции максимальной интенсивности зеленого канала, основанные на Zстеках из $30($ Г) и 70 (Е) оптических срезов.

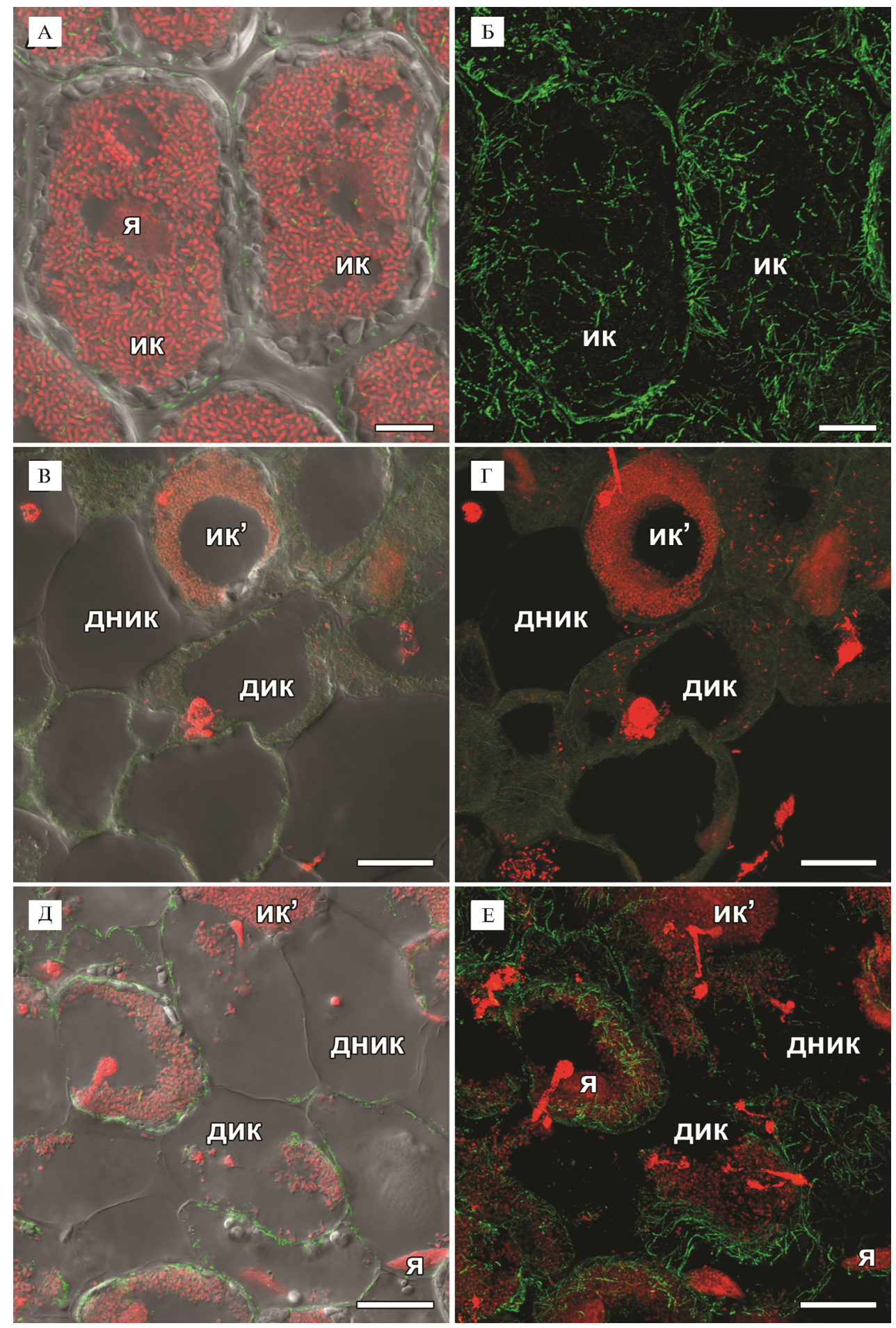

Рис. 3. Организация тубулинового цитоскелета в клетках зоны, соответствующей зоне азотфик- 
сации у исходной линии (А, Б), в клетках из зоны старения (В, Г) 2-недельных клубеньков мутантной линии SGEFix-3 (sym26) и в стареющих клетках (Д, Е) 4-недельных клубеньков исходной линии SGE гороха посевного (Pisum sativum L.): я - ядро, ик - инфицированная клетка, ик' - инфицированная клетка с начальными признаками деградации, ник - неинфицированная клетка, кк - колонизированная клетка, дик - деградирующая инфицированная клетка, дник - деградирующая неинфицированная клетка, стрелки указывают на инфекционные нити. Конфокальная лазерная сканирующая микроскопия продольных срезов клубеньков (микроскоп LSM780, программное обеспечение ZEN2012, «Carl Zeiss», Германия). Масштабные линейки - 10 мкм (А, Б) и 20 мкм (B-E).

A-Е: иммунолокализация тубулина (микротрубочек) - зеленый канал, окрашивание ДНК йодидом пропидия (ядра и бактерии) - красный канал.

А, В, Д: наложение единичных оптических срезов дифференциально-интерференционного контраста, зеленого и красного каналов.

Б: проекции максимальной интенсивности зеленого канала, основанные на Z-стеках из 50 оптических срезов.

Г, Е: проекции максимальной интенсивности зеленого и красного каналов, основанные на Z-стеках из 50 (Г) и 45 (Е) оптических срезов.

В зоне, соответствующей зоне азотфиксации у дикого типа, инфицированные клетки еще больше увеличивались в размерах, при этом в них продолжали поддерживаться неупорядоченные паттерны кортикальных и эндоплазматических микротрубочек, проходящих среди симбиосом (рис. 3, А, Б). Ранее было выявлено участие тубулинового цитоскелета в расположении симбиосом в азотфиксирующих клетках гороха и M. truncatula, причем характер расположения эндоплазматических микротрубочек между симбиосомами различался у проанализированных видов (27). Наблюдаемый паттерн эндоплазматических микротрубочек вокруг симбиосом в инфицированных клетках клубеньков мутантной линии SGEFix ${ }^{-}-3$ (sym26) не отличался от паттерна, выявленного в клубеньках исходной линии SGE.

Сходство паттернов в клубеньках мутантной и исходной линий указывает на то, что процессы развития инфицированных клеток до определенного момента у обоих генотипов протекают сходным образом. Действительно, ранее сообщалось, что для мутантной линии SGEFix--3 (sym26) типичны морфологически дифференцированные бактероиды, которые подвергаются преждевременной деградации (32).

В дистальной части клубенька наблюдалась зона старения (см. рис. 1, Б). В этой зоне в клетках выявили деградацию симбиотических структур, которая сопровождалась полной деполимеризацией как кортикальных, так и эндоплазматических микротрубочек (см. рис. 3, В, Г). Ранее у мутантной линии гороха Sprint-2Fix (sym31) с недифференцированными бактероидами (36) эндоплазматические микротрубочки, располагающиеся среди симбиосом, формировали сходный с диким типом паттерн, в то время как у мутанта $M$. truncatula dnfl-1 (37), также образующего недифференцированные бактероиды, происходила быстрая деполимеризация микротрубочек (27). Вероятно, деполимеризация микротрубочек у мутантной линии SGEFix-3 (sym26) в клетках зоны старения связана с деградацией симбиотических структур (32) и активацией в них процессов реутилизации питательных веществ. Возможно, что быстрая деполимеризация микротрубочек у мутанта $M$. truncatula dnfl-1 связана не с отсутствием дифференцировки бактероидов у этого мутанта, а с активацией процессов деградации симбиотических структур, сопровождаемой разборкой как тубулинового, так и актинового цитоскелета (38).

При анализе 4-недельных клубеньков исходной линии SGE в основании клубенька были выявлены стареющие инфицированные и неинфицированные клетки с признаками деградации симбиотических структур (см. рис. 3, Д, Е). В таких клетках также наблюдалась деполимеризация микро- 
трубочек (см. рис. 3, Д, Е). В 4-недельных клубеньках SGE старение только инициируется, его пик приходится на 6-недельные клубеньки (32). В то же время в 4-недельных клубеньках мутантной линии SGEFix ${ }^{-}-3$ (sym26) происходит почти полная деградация симбиотических структур и зона старения часто занимает весь клубенек (32).

Итак, нами изучено воздействие естественного старения на организацию микротрубочек в клубеньках исходной линии SGE. Также проанализировано влияние на тубулиновый цитоскелет мутации в симбиотическом гене гороха Sym26, приводящей к формированию неэффективных клубеньков, в которых индуцируется преждевременная деградация симбиотических структур. Показано, что организация микротрубочек в клетках меристемы, зоны инфекции и зоны, соответствующей зоне азотфиксации у дикого типа, в клубеньках мутантной линии SGEFix-3 (sym26) не отличается от таковой у исходной линии SGE. Это указывает на нормальное развитие клеток клубенька у мутантной линии до момента индукции преждевременной деградации симбиотических структур с последующей полной разборкой тубулинового цитоскелета как в инфицированных, так и в неинфицированных клетках. Сходная деполимеризация микротрубочек наблюдается и при естественном старении клеток клубеньков исходной линии SGE. Таким образом, полная деполимеризация микротрубочек в различных типах клеток клубенька наблюдается как при естественном, так и индуцированном старении, и ее можно рассматривать как цитологический маркер старения.

\author{
ФГБНУ Всероссийский НИИ сельскохозяйственной \\ микробиологии, \\ 196608 Россия, г. Санкт-Петербург-Пушкин, ш. Подбельского, 3, \\ e-mail: anykitaeva@gmail.com, tsyganov@arriam.spb.ru $\bowtie$
}

Поступила в редакцию

11 февраля 2019 года

Sel'skokhozyaistvennaya biologiya [Agricultural Biology], 2019, V. 54, № 5, pp. 1014-1023

\title{
INFLUENCE OF MUTATION IN THE GENE Sym26 OF THE GARDEN PEA (Pisum sativum L.) ON THE ORGANIZATION OF TUBULIN CYTOSKELETON IN NODULES
}

\section{A.B. Kitaeva, V.E. Tsyganov}

All-Russian Research Institute for Agricultural Microbiology, 3, sh. Podbel'skogo, St. Petersburg, 196608 Russia, e-mail anykitaeva@gmail.com, tsyganov@arriam.spb.ru (₫ corresponding author) ORCID:

Kitaeva A.B. orcid.org/0000-0001-7873-6737

The authors declare no conflict of interests

Tsyganov V.E. orcid.org/0000-0003-3105-8689

Acknowledgements:

The work was carried out on the equipment of the ARRIAM Center for Genomic Technologies, Proteomics and Cell Biology and of the BIN RAS Center for Cell and Molecular Technologies of Studying Plants and Fungi.

Supported financially by Russian Science Foundation (grant № 16-16-10035)

Received February 11, 2019

doi: 10.15389/agrobiology.2019.5.1014eng

\section{Abstract}

Symbiotic nodule is a unique organ forming on legume roots. Indeterminate nodules (with prolonged meristem activity) (F. Guinel, 2009) are characterized by differentiation of both the nodule cells and the bacteria that infect nodule and are converted into a form specialized for nitrogen fixation - bacteroids. Bacteroids surrounded by a membrane of plant origin, form organelle-like symbiosomes (A. Tsyganova et al., 2018; T. Coba de la Peca et al., 2018). Cell differentiation leads to appearance of uninfected (free of bacteria) and infected cells filled with many thousands of symbiosomes formed in the central part of nodule (A. Tsyganova et al., 2018). A prolonged activity of the meristem results in histological zonation of the indeterminate nodule. A meristem, an infection zone, a nitrogen fixation zone are distinguished, and a senescence zone appears in the basal part of a mature nodule (F. Guinel, 2009). Obviously, the tubulin cytoskeleton plays an important role in the development of a nodule, but until now researchers had a focus on the early stages of nodule development (A. Timmers, 2008). Only recently it was revealed that the tubulin cytoskeleton plays a key role in the differentiation of nodule cells (A. Kitaeva et al., 2016). It was shown that in nodules of 
garden pea (Pisum sativum L.) and barrel medic (Medicago truncatula Gaertn.) the release of bacteria into the cytoplasm of a plant cell prevents the formation of a regular pattern of cortical microtubules, oriented parallel to each other and perpendicular to the longitudinal axis of the cell, typical for uninfected cells. This leads to an irregular pattern of cortical microtubules, the appearance of which contributes to the transition of infected cells to isodiametric growth (A. Kitaera et al., 2016). Endoplasmic microtubules build a mold for the growth of infection threads, and support the location of infection droplets and symbiosomes in infected cells (A. Kitaeva et al., 2016). However, changes in the organization of the tubulin cytoskeleton during senescence of nodule cells have not been studied. In this study, using immunocytochemical analysis and confocal laser scanning microscopy, the organization of the tubulin cytoskeleton in the nodules of the pea mutant SGEFix ${ }^{-} 3$ (sym26) (V. Tsyganov et al., 2000) was studied. This mutant is characterized by the formation of ineffective nodules with premature degradation of symbiotic structures (T. Serova et al., 2018). It was shown that in the mutant line, the formed patterns of cortical and endoplasmic microtubules did not differ from those of the initial line SGE. Cortical microtubules formed an irregular pattern in meristematic and infected cells and regular pattern in uninfected and colonized cells. Endoplasmic microtubules surrounded the nucleus in interphase cells, formed spindles and preprophase bands during mitosis, and also surrounded infection threads. At the same time, in the senescence zone in degrading cells, complete depolymerization of the tubulin cytoskeleton occurred in both infected and uninfected cells. In the initial line, senescence was induced only in four-week-old nodules, and microtubule depolymerization was also observed in senescent cells. Thus, the complete depolymerization of microtubules in various types of nodule cells can be a cytological marker of its senescence.

Keywords: legume-rhizobial symbiosis, microtubules, symbiosome, bacteroid, infection thread, nodule senescence, immunolocalization, Pisum sativum.

\section{REFEREN CES}

1. Oldroyd G.E. Speak, friend, and enter: signalling systems that promote beneficial symbiotic associations in plants. Nature Reviews Microbiology, 2013, 11: 252-263 (doi: 10.1038/nrmicro2990).

2. Guinel F.C. Getting around the legume nodule: I. The structure of the peripheral zone in four nodule types. Botany, 2009, 87: 1117-1138 (doi: 10.1139/B09-074).

3. Brewin N.J. Development of the legume root nodule. Annual Review of Cell Biology, 1991, 7: 191-226 (doi: 10.1146/annurev.cb.07.110191.001203).

4. Serova T.A., Tsyganov V.E. Symbiotic nodule senescence in legumes: molecular-genetic and cellular aspects (review). Agricultural Biology [Sel'skokhozyaistvennaya biologiya], 2014: 3-15 (doi: 10.15389/agrobiology.2014.5.3eng).

5. Tsyganova A.V., Kitaeva A.B., Tsyganov V.E. Cell differentiation in nitrogen-fixing nodules hosting symbiosomes. Functional Plant Biology, 2018, 45: 47-57 (doi: 10.1071/FP16377).

6. Coba de la Peca T., Fedorova E., Pueyo J.J., Lucas M.M. The symbiosome: legume and rhizobia co-evolution toward a nitrogen-fixing organelle? Frontiers in Plant Science, 2018, 8: 2229 (doi: 10.3389/fpls.2017.02229).

7. Timmers A.C.J. The role of the plant cytoskeleton in the interaction between legumes and rhizobia. Journal of Microscopy, 2008, 231: 247-256 (doi: 10.1111/j.1365-2818.2008.02040.x).

8. Cárdenas L., Vidali L., Domınguez J., Pérez H., Sánchez F., Hepler P.K., Quinto C. Rearrangement of actin microfilaments in plant root hairs responding to Rhizobium etli nodulation signals. Plant Physiology, 1998, 116: 871-877 (doi: 10.1104/pp.116.3.871).

9. Miller D.D., De Ruijter N.C., Bisseling T. The role of actin in root hair morphogenesis: studies with lipochito-oligosaccharide as a growth stimulator and cytochalasin as an actin perturbing drug. The Plant Journal, 1999, 17: 141-154 (doi: 10.1046/j.1365-313X.1999.00358.x).

10. Yokota K., Fukai E., Madsen L.H., Jurkiewicz A., Rueda P., Radutoiu S., Held M., Hossain M.S., Szczyglowski K., Morieri G. Rearrangement of actin cytoskeleton mediates invasion of Lotus japonicus roots by Mesorhizobium loti. The Plant Cell, 2009, 21: 267-284 (doi: 10.1105/tpc.108.063693).

11. Miyahara A., Richens J., Starker C., Morieri G., Smith L., Long S., Downie J.A., Oldroyd G.E.D. Conservation in function of a SCAR/WAVE component during infection thread and root hair growth in Medicago truncatula. Molecular Plant-Microbe Interactions, 2010, 23: 1553-1562 (doi: 10.1094/MPMI-06-10-0144).

12. Hossain M.S., Liao J., James E.K., Sato S., Tabata S., Jurkiewicz A., Madsen L.H., Stougaard J., Ross L., Szczyglowski K. Lotus japonicus ARPC1 is required for rhizobial infection. Plant Physiology, 2012, 160: 917-928 (doi: 10.1104/pp.112.202572).

13. Qiu L., Lin J.-S., Xu J., Sato S., Parniske M., Wang T.L., Downie J.A., Xie F. SCARN a novel class of SCAR protein that is required for root-hair infection during legume nodulation. PLOS Genetics, 2015, 11: e1005623 (doi: 10.1371/journal.pgen.1005623).

14. Zhang X., Han L., Wang Q., Zhang C., Yu Y., Tian J., Kong Z. The host actin cytoskeleton channels rhizobia release and facilitates symbiosome accommodation during nodulation in Medicago truncatula. New Phytologist, 2019, 221(2): 1049-1059 (doi: 10.1111/nph.15423). 
15. Ridge R.W., Rolfe B.G. Rhizobium sp. degradation of legume root hair cell wall at the site of infection thread origin. Applied and Environmental Microbiology, 1985, 50: 717-720.

16. Turgeon B.G., Bauer W.D. Ultrastructure of infection thread development during infection of soybean by Rhizobium japonicum. Planta, 1985, 163: 328-349 (doi: 10.1007/BF00395142).

17. Timmers A.C., Auriac M.C., Truchet G. Refined analysis of early symbiotic steps of the Rhizobium-Medicago interaction in relationship with microtubular cytoskeleton rearrangements. Development, 1999, 126: 3617-3628.

18. Weerasinghe R.R., Collings D.A., Johannes E., Allen N.S. The distributional changes and role of microtubules in Nod factor challenged Medigaco sativa root hairs. Planta, 2003, 218: 276-289 (doi: 10.1007/s00425-003-1097-1).

19. Sieberer B.J., Timmers A.C., Emons A.M.C. Nod factors alter the microtubule cytoskeleton in Medicago truncatula root hairs to allow root hair reorientation. Molecular Plant-Microbe Interactions, 2005, 18: 1195-1204 (doi: 10.1094/MPMI-18-1195).

20. Vassileva V.N., Kouchi H., Ridge R.W. Microtubule dynamics in living root hairs: transient slowing by lipochitin oligosaccharide nodulation signals. The Plant Cell, 2005, 17: 1777-1787 (doi: 10.1105/tpc.105.031641).

21. Timmers A.C., Vallotton P., Heym C., Menzel D. Microtubule dynamics in root hairs of Medicago truncatula. European Journal of Cell Biology, 2007, 86: 69-83 (doi: 10.1016/j.ejcb.2006.11.001).

22. Perrine-Walker F.M., Lartaud M., Kouchi H., Ridge R.W. Microtubule array formation during root hair infection thread initiation and elongation in the Mesorhizobium-Lotus symbiosis. Protoplasma, 2014, 251: 1099-1111 (doi: 10.1007/s00709-014-0618-z).

23. Timmers A.C., Auriac M.C., de Billy F., Truchet G. Nod factor internalization and microtubular cytoskeleton changes occur concomitantly during nodule differentiation in alfalfa. Development, 1998, 125: 339-349.

24. Whitehead L.F., Day D.A., Hardham A.R. Cytoskeletal arrays in the cells of soybean root nodules: The role of actin microfilaments in the organisation of symbiosomes. Protoplasma, 1998, 203: 194-205 (doi: 10.1007/BF01279476).

25. Davidson A.L., Newcomb W. Organization of microtubules in developing pea root nodule cells. Canadian Journal of Botany, 2001, 79: 777-786 (doi: 10.1139/b01-045).

26. Fedorova E.E., de Felipe M.R., Pueyo J.J., Lucas M.M. Conformation of cytoskeletal elements during the division of infected Lupinus albus L. nodule cells. Journal of Experimental Botany, 2007, 58: 2225-2236 (doi: 10.1093/jxb/erm083).

27. Kitaeva A.B., Demchenko K.N., Tikhonovich I.A., Timmers A.C.J., Tsyganov V.E. Comparative analysis of the tubulin cytoskeleton organization in nodules of Medicago truncatula and Pisum sativum: bacterial release and bacteroid positioning correlate with characteristic microtubule rearrangements. New Phytologist, 2016, 210: 168-183 (doi: 10.1111/nph.13792).

28. Hogetsu T., Oshima Y. Immunofluorescence microscopy of microtubule arrangement in root cells of Pisum sativum L. var Alaska. Plant and Cell Physiology, 1986, 27: 939-945 (doi: 10.1093/oxfordjournals.pcp.a077210).

29. Adamakis I.D.S., Panteris E., Eleftheriou E.P. Tungsten affects the cortical microtubules of Pisum sativum root cells: experiments on tungsten-molybdenum antagonism. Plant Biology, 2010, 12: 114-124 (doi: 10.1111/j.1438-8677.2009.00197.x).

30. Kosterin O.E., Rozov S.M. Mapping of the new mutation blb and the problem of integrity of linkage group I. Pisum Genetics, 1993, 27-31.

31. Tsyganov V.E., Voroshilova V.A., Borisov A.Y., Tikhonovich I.A., Rozov S.M. Four more symbiotic mutants obtained using EMS mutagenesis of line SGE. Pisum Genetics, 2000, 32: 63.

32. Serova T.A., Tsyganova A.V., Tsyganov V.E. Early nodule senescence is activated in symbiotic mutants of pea (Pisum sativum L.) forming ineffective nodules blocked at different nodule developmental stages. Protoplasma, 2018, 255: 1443-1459 (doi: 10.1007/s00709-018-1246-9).

33. Wang T.L., Wood E.A., Brewin N.J. Growth regulators, Rhizobium and nodulation in peas. Planta, 1982, 155: 345-349 (doi: 10.1007/bf00429463).

34. Fehraeus $\mathrm{G}$. The infection of clover root hairs by nodule bacteria studied by a simple glass slide technique. Microbiology, 1957, 16: 374-381 (doi: doi:10.1099/00221287-16-2-374).

35. Tsyganov V.E., Morzhina E.V., Stefanov S.Y., Borisov A.Y., Lebsky V.K., Tikhonovich I.A. The pea (Pisum sativum L.) genes sym 33 and sym 40 control infection thread formation and root nodule function. Molecular and General Genetics, 1998, 259: 491-503.

36. Borisov A.Y., Rozov S., Tsyganov V., Kulikova O., Kolycheva A., Yakobi L., Ovtsyna A., Tikhonovich I. Identification of symbiotic genes in pea (Pisum sativum L.) by means of experimental mutagenesis. Genetika (Russian Federation), 1994, 30: 1484-1494.

37. Wang D., Griffitts J., Starker C., Fedorova E., Limpens E., Ivanov S., Bisseling T., Long S. A nodule-specific protein secretory pathway required for nitrogen-fixing symbiosis. Science, 2010, 327: 1126-1129 (doi: 10.1126/science.1184096).

38. Gavrin A., Jansen V., Ivanov S., Bisseling T., Fedorova E. ARP2/3-mediated actin nucleation associated with symbiosome membrane is essential for the development of symbiosomes in infected cells of Medicago truncatula root nodules. Molecular Plant-Microbe Interactions, 2015, 28: 605-614 (doi: 10.1094/MPMI-12-14-0402-R). 